\title{
左大腿動静脈を人工血管にて再建した滑膜肉腫の一例
}

\author{
福岡大学整形外科 \\ 八並幹・諌山照刀 \\ 毛利 正 玄・古 賀敬 \\ 同 心縢外科 \\ 中 村 克 彦
}

\section{A Case of Synovial Sarcoma Reconstructed Femoral Artery and Vein at Wide Resection}

\author{
Motoki Yatsunami, Teruto Isayama, Seigen Mohri, and Kei Koga \\ Department of Orthopaedics Surgery, Fukuoka University \\ Katsuhiko Nakamura \\ Department of Cardiac Surgery, Fukuoka University
}

\begin{abstract}
A 20 year-old woman with a recurrent tumor was admitted to the Fukuoka University Hospital in October 1995 with 4-year history of each resection for a primary tumor and twice recuring tumors in the left quadriceps at another hospital. The recurrent tumor diagnosed as biphasic type synovial sarcoma involved the femoral artery, vein, and nerve in the left femoral triangle. So it is suspected that MRI demonstrated not only a lesion of the left femoral triangle but also a small lesion of the left vastus lateralis. A curative wide resection of the entire left quadriceps and the left femoral neurovascular band was performed in November 1995. Consequently, the left femoral artery and vein were reconstructed by artificial vessels. After the reconstruction, massive skin necrosis of the left thigh and obstruction of the reconstructed artery wee occured. Rectus abdominal graft for massive skin necrosis and reconstruction for obstruction of the reconstructed artery were then performel. She has been disease-free. 4 years after the last resection.
\end{abstract}

Key words : synovial sarcoma (滑膜肉腫), wide resection (広範切除), artifical vessel (人工血管)

\section{はじめに}

従来, 主要動静脈及び神経を巻き込んだ悪性骨軟部 腫瘍の患肢温存は困難とされてきた。 今回我々は人工 血管を用いて大腿動静脈を再建しえた再発滑膜肉腫の 一例を経験したので報告する.

\section{症例}

症例 : 20 歳, 女性.

\section{主訴 : 左大腿内側の腫瘤, 疼痛}

現病歴: 90 年 (15 歳時) 左大腿内側の腫瘤を触知. 徐々に増大傾向を示したため, 91 年 5 月某医受診. CT 等にて左大腿軟部腫瘤の診断を受ける． 5 月 31 日腫瘍広範切除術施行. 病理診断は滑膜肉腫 (二相性) であった. 93 年 3 月, 一回目の再発を認めたため 4 月 17 日腫瘍広範切除術施行. 95 年 6 月, 二回目の再 発を認めたため 7 月 4 日腫瘍広範切除術施行. 同年 10 月, 三回目の再発を認めたため 10 月 31 日当科紹 
介入院となる. 入院時所見では左大腿内側に直径 $4 \mathrm{c}$ $\mathrm{m}$ の境界明瞭, 可動性不良な腫瘤を触れた。局所の 発赤, 腫脹, 熱感は認めなかった。

\section{画 像 所 見}

初発時, 大腿四頭筋内に大きな腫瘤像を認めた． 2 年後の一回目再発時, 更に 2 年後の二回目再発時は大 腿三角と外側広筋の二力所に腫瘤再発像を認めた（図 1 ).

三回目再発時, MRI T2 強調像にて大腿三角部に腫
瘍像を認め, Gd にて大腿三角と外側広筋の二カ所が enhanceされた。 また, タリウムシンチにて左大腿 近位部に集積像を認めた (図 2 ).

以上の所見より大腿四頭筋及び大腿神経と動静脈を 含めた合併切除が必要と考えられた。

$$
\text { 手術 }
$$

95 年 11 月 13 日左大腿部腫瘍広範切除術施行した。 大腿四頭筋, 縫工筋, 腸腰筋, 大腿筋膜張筋を切除し た. また, 左大腿動静脈, 左大腿神経を合併切除した。

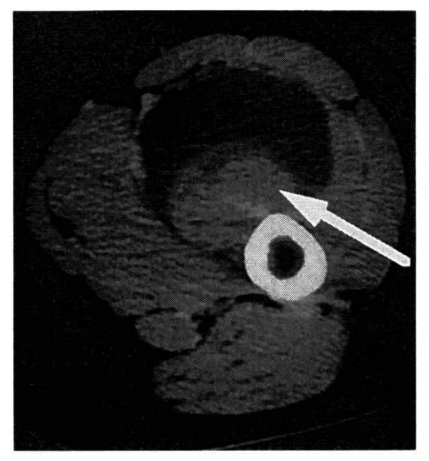

初発時 (91 年 6 月)

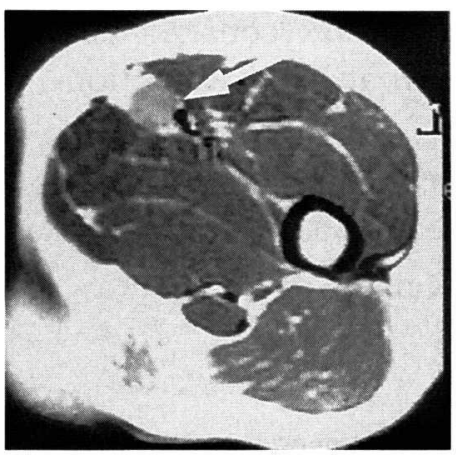

一回目再発時（93 年 3 月）

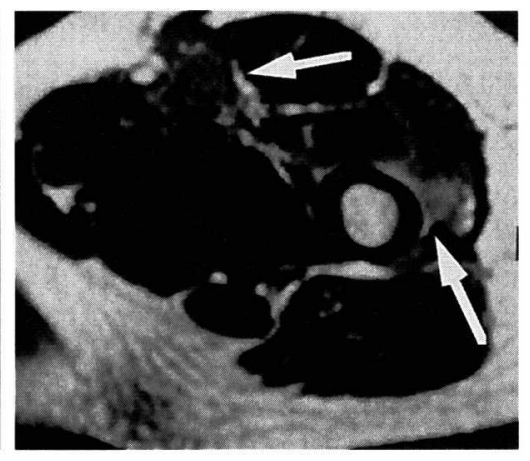

二回目再発時（95 年 6 月）

図1 初発時よりの経時的変化 初発時は大腿四頭筋内に腫瘍像を認め, 一回目再発時は大腿三角, 二回目再発時には大腿三角と外側広筋の二力 所に再発像を認めた.

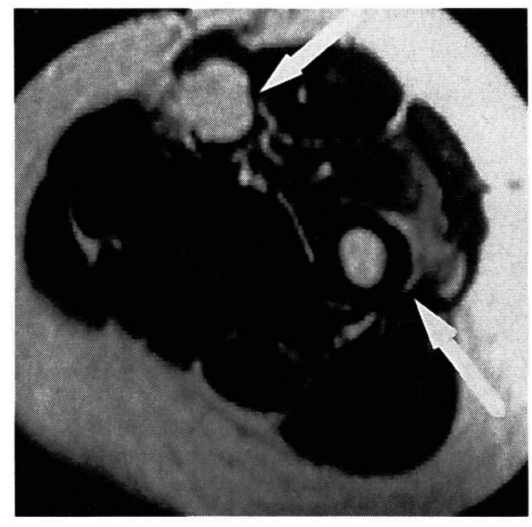

$\mathrm{T} 2$ 强調像

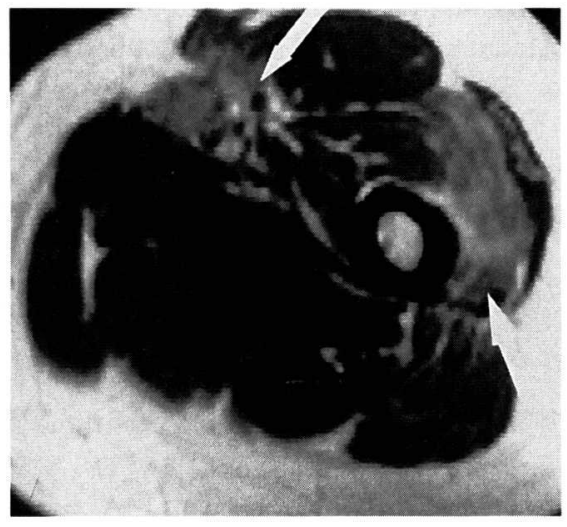

Gd

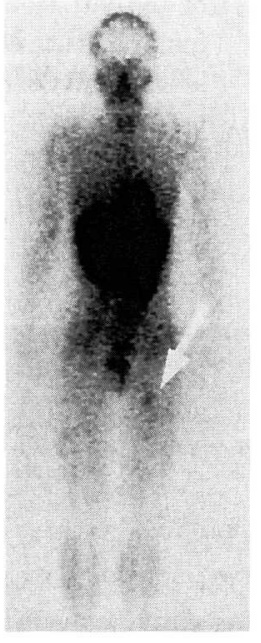

Gd シンチ

図 2 三回目再発時 (95 年 11 月)

MRI T2 強調像に腫瘍像を認め, Gd にて大腿三角と外側広筋が enhance されている．また，ガリウムシンチに て左大腿近位部に集積像を認めた。 
大腿動静脈の再建を行い, 動脈は $6 \mathrm{~mm}$, 静脈は 8 mm の Gore tex graft を使用した.

\section{術 後 経 過}

術直後よりワーファリン内服を開始, 現在む継続中 である，術直後より創部の皮膚壊死が出現，憎悪した ため 96 年 1 月 23 日腹直筋皮弁形成術を施行した. 96 年 3 月 27 日より 7 月 24 日まで CDDP, ADM, IFO, ETOにより化学療法を 4 クール施行した. 97 年 7 月 18 日人工血管閉塞が生じたため総腸骨動脈－膝窩動 脈バイパス術を行った（図 3 )。9 98 年 8 月 24 日左大 腿動脈グラフト遠位吻合部狭窄が生じたためパッチ形 成術を行った。

左膝は伸展筋切除のための伸展不能であるが， 90 度まで屈曲可能であり歩行は正常である．術後 3 年を 経過し, 再発・転移を認めていない.

\section{考察}

従来, 悪性軟部腫瘍の治療体系では切離断術が治療 法の中心をなしていたが 1970 年代以降化学療法・放 射線療法の発達による局所コントロールの向上, 手術 手技・手術材料の発達等を背景として患肢温存手術が
発達してきた ${ }^{11}$. 本症例むその患肢温存手術の延長線 上の一例で, 動静脈の再建材料として人工血管を使用

している. 人工血管の合併症としては, 1 , 血栓形成 による循環不全及び塞栓症， 2 ，血管吻合部における 出血, 3 , 感染などが挙げられている. 今回の症例で は血栓形成を生じたが出血・感染は生じていない。

現在, 腫場の再発・転移と人工血管の障害は生じて いないが，今後むワーファリン等抗凝固剤の持続投与 之凝固機能の定期的検査が必要である. 今後, 左下肢 痛・跛行等の人工血管の障害が予想される症状の出現 を認めた場合は血管造影の施行が必要とされる.

$$
\text { 結 語 }
$$

1. 今回我々は左大腿動静脈を人工血管により再建し た二相性滑膜肉腫の一例を経験した。

2. 再建術後, 人工血管の合併症等様々なトラブルが 発生し, 状態が安定するまでに困難を伴った。

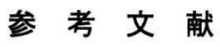

1）新図説臨床整形外科講座 第 13 巻 骨・軟部腫瘍お よび類似疾患 Medical view 社

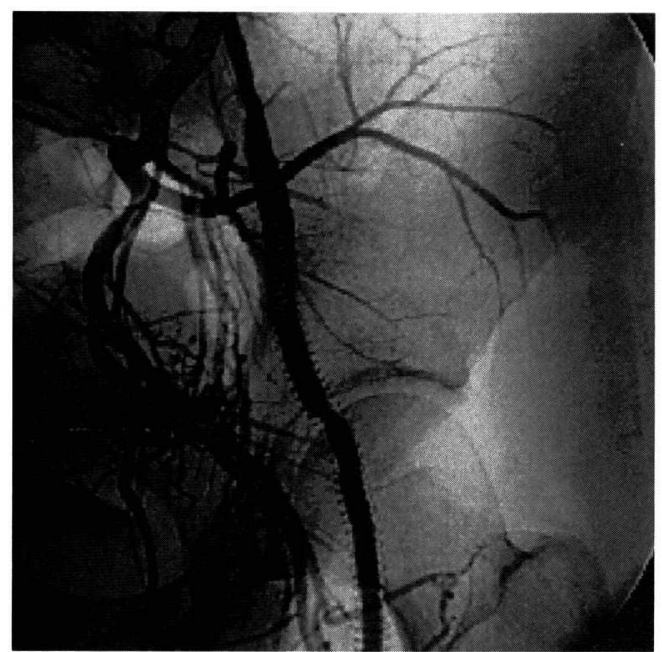

バイパス術後（97 年 9 月）

人工血管閉塞時 $(97$ 年 7 月)

図 3 血管造影所見

97 年 7 月に施行した血管造影にて人工血管に閉塞を認めた.

8 月 24 日バイパス術を施行.

9 月に施行した血管造影では血行は良好であった。 